\title{
PENERAPAN ART THERAPY UNTUK MENINGKATKAN SELF-ESTEEM ANAK USIA MIDDLE CHILDHOOD
}

\author{
Alvina $^{1}$ dan Woro Kurnianingrum ${ }^{2}$ \\ 1Fakultas Psikologi, Universitas Tarumanagara Jakarta \\ Email: alvinawongg@gmail.com \\ 2 Fakultas Psikologi, Universitas Tarumanagara Jakarta \\ Email: woro_kurnianingrum@yahoo.com
}

\begin{abstract}
ABSTRAK
Self-esteem merupakan salah satu aspek pada diri yang memiliki peran penting pada tiap tahap kehidupan seseorang. Pembentukkan self-esteem pada seorang anak dapat dipengaruhi oleh beberapa hal, salah satunya adalah teman sebaya, di mana anak-anak menjalin interaksi dengan teman sebayanya, sehingga pengalaman-pengalaman yang didapatkan selama interaksi tersebut menjadi salah satu faktor yang cukup berpengaruh pada anak usia sekolah ini dalam hal pembentukkan self-esteem mereka. Di usia middle childhood, anak memasuki tahap industry versus inferiority, di mana anak harus mempelajari kemampuan produktif yang dibutuhkan atau anak akan menghadapi inferioritas. Oleh sebab itu, art therapy diterapkan dalam penelitian ini sebagai upaya untuk meningkatkan selfesteem dari lima anak usia middle childhood. Kelima partisipan menunjukkan perilaku tidak percaya diri yang dikeluhkan oleh guru kelas. Penelitian ini menggunakan quantitative one group pre-test post-test design, di mana alat ukur self-esteem dan grafis dianalisa untuk mengetahui perbandingan hasil sebelum dan sesudah pemberian intervensi. Kesimpulan dari penelitian ini menunjukkan bahwa art therapy tergolong efektif untuk meningkatkan selfesteem pada anak usia middle childhood.
\end{abstract}

Kata kunci: art therapy, self-esteem, anak usia middle childhood

\section{PENDAHULUAN}

\section{Latar belakang}

Anak usia sekolah dasar atau yang tergolong dalam masa perkembangan middle childhood, pada umumnya berada dalam proses perkembangan yang berlangsung dengan cepat pada aspek fisik, emosional, intelektual, dan sosial (Papalia, Olds, \& Feldman, 2009). Dalam tahap perkembangan tersebut, hambatan atau masalah juga sering muncul. Hambatan atau masalah yang pada umumnya terjadi di masa perkembangan ini dapat berupa perilaku yang keliru yang dapat merugikan, baik untuk dirinya sendiri ataupun orang lain. Perilaku yang ditunjukkan dapat berupa perilaku yang positif dan perilaku yang negatif, yang salah satunya dapat berupa perilaku pasif yang disebabkan oleh perasaan tidak puas terhadap diri sendiri.

Pada masa perkembangan ini, anak akan mengalami masalah-masalah yang berkenaan dengan perkembangan individu dan perbedaan individu dalam hal kecerdasan, kecakapan, hasil belajar, bakat, sikap, kebiasaan, pengetahuan, kepribadian, cita-cita, kebutuhan, minat, pola-pola, tempo perkembangan, ciri-ciri jasmaniah, dan latar belakang lingkungan. Terdapat juga perbedaan kebutuhan individu dalam hal memperoleh kasih sayang, memperoleh harga diri, memperoleh penghargaan yang sama, ingin dikenal, memperoleh prestasi dan posisi, untuk dibutuhkan orang lain, merasa bagian dari kelompok, rasa aman dan perlindungan diri, dan untuk memperoleh kemerdekaan diri. Perbedaan kemampuan penyesuaian diri pada anak, juga mampu mempengaruhi perbedaan tingkah laku.

Menurut Erikson (dalam dalam Papalia, Olds, \& Feldman, 2009), pada usia ini anak memasuki tahap industry versus inferiority. Pada tahap perkembangan ini, anak harus mempelajari 
kemampuan produktif yang dibutuhkan atau anak akan menghadapi inferioritas. Hal penting bagi anak adalah untuk mengevaluasi bahwa dirinya mampu untuk menguasai keterampilan yang dibutuhkan dan menyelesaikan tugas yang diberikan. Kepercayaan orangtua terhadap kemampuan anak sangat penting bagi kepercayaan anak terhadap kemampuannya sendiri (Fredricks \& Eccles, dalam Papalia, Olds, \& Feldman, 2009). Pada tahap ini, anak yang merasa tidak mampu untuk produktif atau merasa tidak mampu untuk menguasai keterampilan yang dibutuhkan, cenderung akan menunjukkan perilaku yang pasif di lingkungan sosial dan memiliki penilaian diri yang kurang atau merasa kurang puas terhadap dirinya sendiri (Papalia, Olds, \& Feldman, 2009).

Self-esteem atau keyakinan dan kepuasan terhadap diri sendiri, merupakan salah satu aspek diri yang memiliki peran penting pada tiap tahap kehidupan seseorang (Woolf et al., 1976). Selfesteem, secara spesifik, tidak hanya memberikan keyakinan serta sense of competence untuk menghadapi berbagai tantangan dalam hidup seseorang, namun juga sangat mempengaruhi perilaku yang individu tunjukkan (Orth, Robins, \& Roberts, 2008; Trzesniewski et al., 2006). Selfesteem seseorang akan terus mengalami perubahan seiring dengan berjalannya waktu (Papalia, Olds \& Feldman, 2009).

Pembentukkan self-esteem pada seorang anak dapat dipengaruhi oleh beberapa hal, salah satunya adalah teman sebaya. Sebagai lingkungan sosial yang lebih luas dari keluarga, sekolah menjadi tempat berinteraksi anak-anak selain dengan anggota keluarganya. Di sekolah, anak-anak menjalin interaksi dengan teman sebayanya, sehingga pengalaman-pengalaman yang didapatkan selama interaksi tersebut menjadi salah satu faktor yang cukup berpengaruh pada anak usia sekolah ini dalam hal pembentukkan self-esteem mereka. Oleh sebab itu, pengalaman buruk yang didapatkan selama proses interaksi berlangsung dengan teman sebaya, dapat mempengaruhi pembentukkan self-esteem menjadi kurang baik (Deaux, Dane, \& Wrightsman, 1993).

Saat ini, lima dari dua belas murid kelas 4 SD di sebuah komunitas bernama HOME dinilai sebagai anak yang pasif dan tidak memiliki rasa percaya diri terhadap kemampuan yang dimiliki. Hal tersebut terlihat dari selama proses pembelajaran berlangsung, lima anak tersebut terlihat pasif, kurangnya inisiatif untuk menjawab pertanyaan yang diberikan oleh guru di kelas, dan merasa tidak percaya diri untuk menjawab pertanyaan atau melakukan sesuatu saat diminta untuk maju ke depan.

Salah satu intervensi yang dapat diterapkan untuk menangani masalah terkait self-esteem adalah dengan menggunakan pendekatan art therapy. Dalam hal ini, art therapy merupakan proses terapeutik yang menggunakan media seni sebagai asesmen dan intervensi. Penggunaan aktivitas seni sebagai terapi didasarkan pada asumsi bahwa gambar merupakan bentuk komunikasi dimana jarang dilakukan resistensi oleh anak, dan memberi anak cara baru untuk mengekspresikan pikiran dan perasaannya (Malchoidi, 2003).

Hal tersebut juga diketahui dari beberapa penelitian yang telah dilakukan sebelumnya. Penelitian yang dilakukan oleh Alavinezhad, Mousavi, dan Sohrabi (2014) menghasilkan bahwa art therapy tergolong efektif untuk meningkatkan self-esteem pada anak usia middle childhood yang juga menunjukkan perilaku agresif. Penelitian yang dilakukan oleh Tripathi (2015) juga menyatakan bahwa art therapy merupakan salah satu penerapan yang dapat digunakan untuk meningkatkan self-esteem. Hanya saja, penelitian lain yang dilakukan oleh Pesso-Aviv, Regev, dan Guttmann (2014) menghasilkan hasil yang berbeda dari dua penelitian sebelumnya, yaitu penerapan art therapy tergolong kurang efektif untuk meningkatkan self-esteem yang dimiliki oleh para partisipan penelitian, yaitu pada anak usia middle childhood. Hal tersebut disebabkan oleh 
kemungkinan dari ketidakpercayaan diri anak yang kurang bertalenta dalam hal seni. Hal ini juga didukung oleh tidak dilakukannya komunikasi secara verbal serta motivasi secara verbal terhadap hasil seni atau gambar yang telah dibuat oleh anak, sehingga anak yang merasa bahwa seni atau gambar yang dibuat tidak seindah anak lainnya, menjadi lebih merasa tertekan dan semakin merasa tidak percaya diri. Oleh sebab itu, peneliti ingin melakukan penelitian kembali terkait efektivitas art therapy untuk meningkatkan self-esteem pada anak usia middle childhood.

\section{Rumusan masalah}

Apakah art therapy dapat diterapkan untuk meningkatkan self-esteem pada anak usia middle childhood di komunitas HOME?

\section{Tujuan penelitian}

Tujuan dari penelitian ini adalah menerapkan art therapy sebagai upaya meningkatkan self-esteem pada anak usia middle childhood di komunitas HOME.

\section{METODE PENELITIAN}

Partisipan penelitian. Lima anak usia middle childhood dengan jenis kelamin perempuan yang berpartisipasi dalam art therapy memiliki karakteristik sebagai berikut: (a) berada dalam tahapan anak usia middle childhood (6 - 11 tahun), (b) memperoleh skor inteligensi yang termasuk dalam golongan rata-rata atau di atas rata-rata, (c) dikeluhkan oleh guru merupakan anak yang pasif dan kurang percaya diri, (d) memperoleh skor yang lebih rendah dari 163,2 (skor= $<163,2)$ pada alat ukur self-esteem.

Desain penelitian. Penelitian ini menggunakan quantitative one group pre-test post-test design, dimana kuesioner self-esteem dari Nugent dan Thomas (1993) dianalisa untuk mengetahui perbandingan hasil sebelum dan sesudah pemberian intervensi.

Lokasi penelitian. Penelitian ini dilakukan di HOME (House of Mercy), yang merupakan sebuah komunitas dengan tujuan bersosialisasi untuk menjangkau, melayani, mendidik, dan membidik generasi untuk membuat terobosan dan menjadi sebuah solusi. HOME berlokasi di Cilincing Tanjung Priok, Jakarta Utara.

Instrumen penelitian. Peralatan yang digunakan dalam penelitian ini meliputi lembar informed consent, alat ukur self-esteem yang dikembangkan oleh Nugent dan Thomas (1993), alat ukur Culture Fair Intelligence Test (CFIT), tes grafis Draw-A-Man (DAM), lembar observasi, lembar wawancara, alat tulis, lembar aktivitas dalam manual art therapy: kertas ukuran A4, kertas ukuran A3, spidol berwarna, pensil warna, krayon, dan snack.

Pengukuran. Kuesioner self-esteem mengacu pada enam dimensi dari Nugent dan Thomas (1993) dengan skala Likert, dimana terdapat lima pilihan jawaban, yaitu Sangat Tidak Setuju (STS), Tidak Setuju (TS), Ragu-ragu (R), Setuju (S), Sangat Setuju (SS). Enam dimensi tersebut adalah keseluruhan harga diri, kompetensi sosial, kemampuan memecahkan masalah, kemampuan intelektual, kompetensi diri, perasaan berharga di mata orang lain. Skoring untuk item favorable adalah $\mathrm{STS}=1$, TS=2, $\mathrm{R}=3, \mathrm{~S}=4$, dan $\mathrm{SS}=5$. Sedangkan untuk item unfavorable adalah $\mathrm{STS}=5$, $\mathrm{TS}=4, \mathrm{R}=3, \mathrm{~S}=2, \mathrm{SS}=1$. Semakin tinggi total skor mengindikasikan semakin tinggi juga nilai selfesteem seorang anak dan sebaliknya.

Prosedur penelitian. Setelah kelima murid kelas 4 SD dirujuk oleh pihak HOME, pre-test untuk mengetahui tingkat self-esteem dilakukan dengan mengadministrasikan alat ukur self-esteem. 
Observasi dan wawancara autoanamnesa dengan kelima anak juga dilakukan untuk mengetahui gambaran partisipan. Alat ukur self-esteem akan kembali diadministrasikan setelah sesi terakhir dari intervensi dilaksanakan sebagai post-test. Hasil pre-test dan post-test kemudian akan dibandingkan untuk mengetahui dampak dari program intervensi terhadap tingkat self-esteem dari kelima anak usia middle childhood.

Pelaksanaan intervensi. Intervensi art therapy yang dijala

nkan berjumlah 6 sesi. Durasi dari setiap sesi akan berkisar antara 50 hingga 80 menit. Kegiatan yang dilaksanakan pada tiap sesi didasarkan pada 5 tahapan yang perlu dilakukan dalam art therapy, yaitu tahap "Warm-Up", "Recalling Event", "Emotional Expression and Issues", "Restitution", dan "Termination".

\section{HASIL DAN PEMBAHASAN}

Total skor skala self-esteem yang diperoleh dari kelima partisipan sebelum mengikuti intervensi menunjukkan perbedaan skor setelah menjalankan 6 sesi intervensi (lihat Tabel 1). Total skor dari ketiga partisipan, yaitu AR, SA, dan AP, menunjukkan peningkatan, sedangkan partisipan JM dan WM menunjukkan skor dalam kategori yang sama seperti sebelum intervensi dilakukan. AP, yang mendapat total skor 160 pada pre-test, memperoleh skor total 177 pada post-test. SA, yang mendapat total skor 159 pada pre-test, memperoleh skor total 189 pada post-test. Selain itu, AR, yang mendapat total skor 162 pada pre-test, memperoleh skor total 170 pada post-test. Dua partisipan lain yang menunjukkan total skor dalam kategori yang sama seperti sebelum intervensi dilakukan adalah WM dan JM. WM, mendapat total skor 150 pada pre-test, memperoleh skor total 152 pada post-test. Kemudian, JM, yang mendapat total skor 151 pada pre-test, memperoleh skor total 154 pada post-test. Hanya saja, skor total yang ditunjukkan oleh JM dan WM menunjukkan peningkatan dalam total skor, walaupun berada dalam kategori yang sama seperti sebelum intervensi diberikan.

Tabel 1. Skor Total pada Pre-Test dan Post-Test

\begin{tabular}{ccccccccccc}
\hline & \multicolumn{2}{c}{ AP } & \multicolumn{2}{c}{ SA } & \multicolumn{2}{c}{ AR } & \multicolumn{2}{c}{ WM } & \multicolumn{2}{c}{ JM } \\
\hline & Pre- & Post- & Pre- & Post- & Pre- & Post- & Pre- & Post- & Pre- & Post- \\
\hline $\begin{array}{l}\text { Skor } \\
\text { total }\end{array}$ & 160 & 177 & 159 & 189 & 162 & 170 & 150 & 152 & 151 & 154 \\
\hline
\end{tabular}

Terdapat perubahan yang tergolong signifikan pada mean dari skor total kelompok pada post-test saat dibandingkan dengan mean skor total kelompok pada pre-test (lihat Grafik 1). 


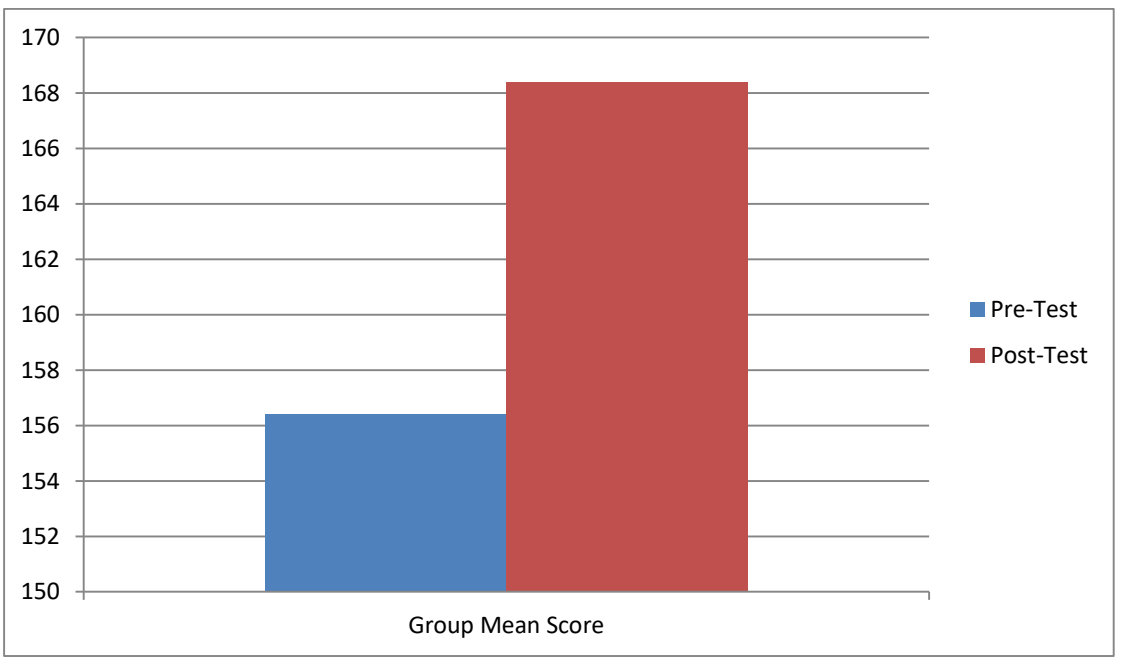

Grafik 1. Mean dari skor total kelompok pada pre-test dan post-test

Di sesi pertama, pada tahap warm-up, partisipan diminta untuk membuat garis tanpa putus atau yang biasa disebut dengan garis scribble dan membuat gambar bebas. Seluruh partisipan terlihat bersemangat saat membuat garis tanpa putus tersebut. Secara keseluruhan, partisipan tergolong kooperatif. Partisipan yang paling cepat menyelesaikan gambar dan mewarnai adalah WM dan partisipan yang paling membutuhkan waktu paling lama adalah JM. Partisipan JM, AP, dan SA juga sering melihat gambar milik temannya dan mempertanyakan gambar apa yang dibuat oleh temannya. Setelah selesai menggambar, partisipan menutup gambar mereka dengan membalikkan kertas. Saat diminta untuk menceritakan gambar yang dibuat, seluruh partisipan menyatakan bahwa mereka malu, kecuali WM, sehingga pada akhirnya partisipan menceritakan gambar dengan volume suara yang kecil.

Pada tahap recalling event, disesi ke dua dan ke tiga, partisipan diminta untuk menggambarkan pengalaman positif atau menyenangkan dan menggambarkan pengalaman buruk yang pernah dialami oleh partisipan. Secara keseluruhan, pada tahap ini, kelima partisipan menggambarkan pengalaman buruk mereka yang diperoleh dari lingkungan sosial yang memberikan komentar buruk kepada partisipan, khususnya dalam hal penampilan, seperti pakaian yang digunakan, penampilan fisik yang dinilai kurang, sampai prestasi sekolah yang dinilai buruk oleh lingkungan sosial. Secara keseluruhan, seluruh partisipan mampu menceritakan pengalaman menyenangkan serta pengalaman buruk mereka, namun dengan volume suara yang tergolong kecil dan perbendaharaan kata yang singkat.

Pada tahap emotional expression and issues di sesi ke empat, partisipan diminta untuk menggambarkan hubungan dengan lingkungan sosial, dengan tujuan untuk mengetahui dukungan yang diterima oleh partisipan dari lingkungan sosialnya. Secara keseluruhan, kelima partisipan menggambarkan lingkungan keluarga, terlihat bahwa beberapa partisipan memiliki anggota keluarga yang cenderung memiliki figur otoritas menurut masing-masing partisipan.

Disesi ke lima, pada tahap restitutions, partisipan diminta untuk menggambarkan figur positif yang terdapat dikehidupan partisipan. Hal ini bertujuan untuk memberikan motivasi terhadap perilaku 
positif yang dapat dinilai dan dicontoh oleh masing-masing partisipan dari figur positif tersebut. Secara umum, partisipan memulai gambar dalam jangka waktu yang singkat dan juga menggambar dalam jangka waktu yang singkat. Partisipan menggambarkan figur positif mereka adalah ibu kandung dan teman. Seluruh partisipan juga mampu menuliskan sikap-sikap positif yang dimiliki oleh figur positif menurut partisipan tersebut.

Pada sesi terakhir, ditahap termination, kelima partisipan diminta untuk membuat sebuah karya menggunakan koran atau majalah bekas dengan cara menempelkan potongan-potongan kertas di sebuah kertas kosong berukuran A3. Kelima partisipan juga diperbolehkan untuk menghias karya yang dibuat tersebut. Karya yang dibuat akan diberi judul atau teman "Aku Ingin Menjadi". Kelima partisipan terlihat bersemangat dan langsung menjalankan instruksi yang diberikan. Secara keseluruhan, kelima partisipan menggambarkan ingin merubah penampilan mereka, kecuali JM, karena JM hanya ingin merubah situasi bahwa ia ingin sering berpergian ke tempat dengan banyak permainan yang sesuai dengan anak seusianya.

\section{KESIMPULAN DAN SARAN}

Intervensi kelompok dengan menggunakan pendekatan art group therapy dapat meningkatkan self-esteem pada ketiga partisipan, yaitu AP, AR, dan SA. Peningkatan self-esteem, dapat terlihat dari skor total antara pre-test dan post-test pada skala self-esteem dan hasil tes grafis DAM. Selain itu, dilengkapi juga dari hasil wawancara terhadap partisipan dan guru yang mengajar di HOME, setelah dilakukannya intervensi. Ketiga partisipan menunjukkan peningkatan self-esteem, yaitu dengan peningkatan skor total di skala self-esteem dan ukuran gambar yang tergolong lebih besar. Berdasarkan hasil ini, dapat disimpulkan bahwa efektivitas dari art group therapy untuk meningkatkan self-esteem dari lima anak usia middle childhood di komunitas HOME tergolong cukup efektif.

Selain itu, intervensi kelompok ini juga bermanfaat terhadap relasi antara kelima partisipan. Relasi antara kelima partisipan juga mengalami perubahan ke arah yang lebih positif, yaitu kelima partisipan lebih sering berinteraksi satu sama lain dibandingkan dengan sebelum dilakukannya intervensi. Berdasarkan uraian di atas, dapat disimpulkan bahwa manfaat yang diperoleh dari kegiatan intervensi kelompok ini, antara lain partisipan lebih memiliki kepercayaan diri terhadap dirinya, lebih mengetahui kelebihan dirinya, mengetahui kemampuan yang dimiliki, dan mengetahui dukungan-dukungan yang terdapat di lingkungan sosial. Salah satunya adalah partisipan AR, yang menyadari bahwa walaupun AR sering diejek oleh teman bermainnya karena memiliki tubuh yang kurang tinggi dibandingkan anak lainnya, sampai tidak mampu mencapai lompatan saat bermain lompat tali, namun AR menyadari bahwa ia memiliki kemampuan lain yang belum tentu dimiliki oleh teman bermain lainnya, yaitu AR yang memiliki suara yang indah dan pandai bernyanyi. Selain itu, terdapat juga feedback yang diperoleh dari group leader dan temanteman lainnya, yaitu masing-masing partisipan dapat memperoleh penilaian positif tentang dirinya sendiri.

\section{Saran untuk penelitian selanjutnya.}

Tiga saran yang dapat dipertimbangkan untuk penelitian selanjutnya, diantara lain: (a) menambah sesi terapi agar partisipan memperoleh kesempatan yang lebih banyak untuk melalui proses intervensi, sehingga hasil yang diperoleh dapat lebih signifikan dan optimal; (b) mengatur jadwal yang tepat dengan pihak lembaga terkait, yaitu House of Mercy (HOME), sehingga sesi terapi dapat berjalan sesuai dengan jadwal yang telah ditentukan sebelumnya; dan (c) memperhatikan ruangan yang digunakan untuk menjalankan intervensi, diharapkan pada peneliti selanjutnya, 
ruangan yang digunakan memiliki fasilitas yang sesuai untuk melakukan intervensi, seperti meja dan kursi untuk melakukan aktivitas intervensi, seperti menggambar dan lainnya.

\section{Ucapan Terima Kasih.}

Ucapan terima kasih kepada partisipan yang telah bersedia meluangkan waktu untuk diwawancara dan bekerja sama selama menjalankan intervensi. Peneliti juga mengucapkan terima kasih kepada komunitas House of Mercy (HOME) yang bersedia menjadi objek penelitian.

\section{REFERENSI}

Alavinezhad, R., Mousavi, M., \& Sohrabi, N. (2014). Effects of art therapy on anger and selfesteem in aggressive children. Procedia Social and Behavioral Science, 7, 111-117, DOI https://doi.org/10.1016/j.sbspro.2014.01.016

Deaux, K., Dane, F. C., \& Wrightsman, L. S. (1993). Social Psychology in the 90s (6th ed). California: Brooks/Cole Publishing Company.

Nugent, W. R. \& Thomas, J. W. (1993). Self-esteem rating scale: Psychological indicators - an annotated collection of instrument. USA: Research Triangel Park.

Orth, U., Robins, R. W., \& Roberts, B. W. (2008). Low self-esteem prospectively predicts depression in adolescence and young adulthood. Journal of Personality and Social Psychology, 95, 695-708.

Page, A., \& Page, C. (2000). Kiat meningkatkan harga diri anda (Yunita penerj.). Jakarta: Penerbit Arcan. (karya asli diterbitkan tahun 2005, Melbourne, Australia: Gore \& Osment Publication.)

Papalia, D. E., Olds, S. W., \& Feldman, R. D. (2009). Human development (11th ed). New York, NY: McGraw-Hill International Edition.

Pesso-Aviv, T., Regev, D., \& Guttmann, J. (2014). The unique therapeutic effect of different art materials on psychological aspects of 7-to 9-year-old children. Elsevier: The arts in psychotherapy, 41(3), 293-301, DOI: https://doi.org/10.1016/j.aip.2014.04.005

Rubin, J. A. (2005). Child art therapy. New Jersey: John Willey \& Sons.

Taghva, N. \& Nezhadi, F. (2010). Using Art therapy methods to investigate aggression and revenge in children. Diakses dari http://www.inter-disciplinary.net/wpcontent/uploads/2010/06/Taghva-Paper.pdf

Tri Putri, S. (2014). Penerapan cognitive-behavior group therapy untuk meningkatkan self-esteem remaja pria di lembaga pemasyarakatan anak. Tesis tidak diterbitkan. Magister Psikologi, Universitas Tarumanagara, Jakarta.

Tripathi, N. (2015). Assessing self using art therapy: A case analysis. iMedPub Journal, 1(4), ISSN 2471-9897.

Trzesniewski, K. H., Donnellan, M. B., Moffitt, T. E., Robins, R. W., Poulton, R., \& Caspi, A. (2006). Low self-esteem during adolescence predicts poor health, criminal behavior, and limited economic prospects during adulthood. Developmental Psychology, 42, 381-390.

Wells, K. R. (2016). Self-esteem. Retrieved from http://www.healthofchildren.com/S/SelfEsteem.html.

Woolf, H. B., Artin, E., Crawford, F. S., Gilman, E. W., Kay, M. W., \& Pease Jr., R. W. (Eds.). (1976). Webster's new collegiate dictionary. Springfield, MA: G. \& C. Merriam.

Young, B. B. (1991). How to develop self-esteem in your child: 6 vital ingredients. New York, NY: Fawcett Columbine. 